\title{
Those who require '[...] the burning of incense in synagogues are the Rabbinic Jews': Burning incense in synagogues in commemoration of the temple

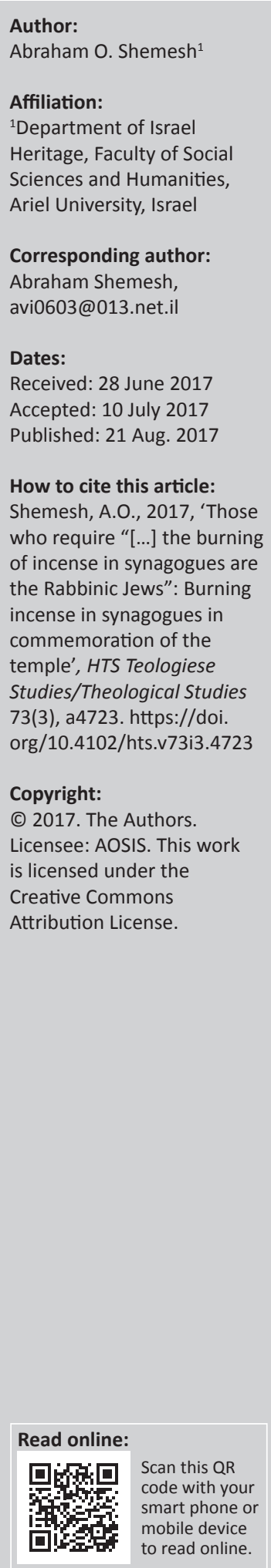

This article focuses on the burning of incense in synagogues subsequent to the destruction of the temple, in commemoration of the incense formerly used in the temple rites. We hear about the implementation of this custom in Samaritan and Rabbinic synagogues only several centuries after the destruction of the Samaritan and Jewish Temples. The Samaritans still burn incense in their synagogues at certain times, but among Rabbinic Jews the custom came to an end, probably in the Middle Ages. Burning incense in the synagogue was a point of controversy between the Karaites and the Rabbinic Jews. The Karaites argued that acts involving burning incense and lighting candles are only appropriate for the Temple and their status is like that of sacrifices or offerings that are limited to this complex. It may have been that the rabbinic custom discontinued as a result of the strict Karaite objections to this custom for concern of idolatry. In fact, burning incense in commemoration of the Temple indeed ceased, but this practice remained in evidence until the 19th century for purposes of conveying respect or on festive occasions.

\section{Introduction}

The use of aromatic substances in ritual settings is a common practice in religions around the world, from ancient times to the present. The burning of various ingredients, primarily plants such as roots, rhizomes and types of resin, was practiced in the cults of Babylon, Egypt, Greece and Rome, and also in the Hebrew Tabernacle (Ex 30:34-35) and in the Temple rites (Babylonian Talmud, Keritut 6b). ${ }^{1}$

In several Jewish communities in Eastern countries, as well as Yemen and Europe, perfumes and incense were utilised in synagogues on Sabbath Eve and holidays, for instance on Simchat Torah, Rosh Hodesh and Chanukah (Hadadi 1865:122; Ibn Giat 1861:1, 117; Nordlingen 1965:127). Burning incense in synagogues in times of distress, as related by R. David ibn Zimra (1882:III, 405) who operated in Egypt and in the Land of Israel in the 16th century, is associated with the fundamental role of this institution as the 'gate to heaven', that is, a place of prayer, entreaties and supplications.

The act of burning incense and of suffusing the prayer room with fragrances formed part of the festive atmosphere on Sabbaths and holidays. The scents honoured the sacred expanse, induced a pleasant atmosphere among the congregants, and maybe even contributed to increasing their fervour during prayers, to a certain degree. Furthermore, perfumes and incense communicated meaningful Jewish ideas and concepts, for example, the sacrifices offered by the leaders of the 12 tribes (Num 7:1-87) and the temple rites that reflect the relationship between Israel and God.

This article focuses on the burning of incense in synagogues subsequent to the destruction of the temple, in commemoration of the incense formerly used in the temple rites. The practice is associated with perception of the synagogue in Jewish consciousness over the generations as a mikdash me'at [literally, 'diminished temple'], a term that received special significance after the destruction of the Second Temple, when the synagogue received the status of an alternative spiritual institution. As I shall show below, this custom was discontinued over time, and in the medieval period it was at the centre of a controversy between Karaites and Rabbinic Jews.

1.On the incense substances of the Jewish temple, their identification and sources (see Amar 2002:56-126; Felix 1976:246-260). On the way of preparing the incense (see Amar 2002:41-52; Felix 1997:23-28). 


\section{'In commemoration of the Temple': The biblical period}

Burning incense in commemoration of the Temple, albeit not in a synagogue context, may have begun not long after the destruction of the First Temple in 586 BCE. Jeremiah 41:5 tells of 80 people from Nablus, Shiloh and Samaria who ascended to the Temple in Jerusalem a short time after it was burned, bearing grain offerings and frankincense. This enigmatic story, which has been given various interpretations, occurred about 2 months after the destruction of the First Temple, and immediately following the death of Gedaliah ben Ahikam, whom the Babylonians had appointed governor of the residents of Judea.

The scholars proposed two interpretations of these events. According to one version, upon setting out from their towns the pilgrims did not know that the Temple had been burned, and when they learned of this along the way they rent their clothes and practiced other mourning customs but did not interrupt their journey and continued onwards to Jerusalem (Artom \& Cassuto 1976:127-128; Bula 1984:507; McKane 1996:1019). They may have refused to accept the new reality forced upon them or had not known how to proceed in the absence of a Temple and of the ritual proceedings. It appears that there was no prohibition or religious ban against offering sacrifices and burning incense in the Temple complex despite the destruction of the building itself, and therefore even after the destruction the rituals were not completely terminated. It is interesting that the Babylonian regime permitted the Jewish pilgrims to hold the ceremony of bringing the offerings and burning frankincense in the temple ruins, but this permit may have been limited to specific types of offerings (Lifshitz 1998).

According to another interpretation, the pilgrims may have known that the Temple had been destroyed before they set out and they sought to offer a type of memorial sacrifice to the ruined Temple (Artom \& Cassuto 1976:127-128; Bula 1984:507). Whether they heard about the destruction and nonetheless continued on their way or set out knowingly, this may be the first early testimony to the custom of burning incense in commemoration of the Temple. Then again, the custom may also have developed independently, unrelated to this event and unaffected by it.

\section{Rulings and customs in commemoration of the temple in the Mishnaic and Talmudic period}

In the Mishnaic period, after the destruction of the Second Temple in $70 \mathrm{CE}$, the sages instituted several customs and rulings in commemoration of the Temple. Some of these customs and rulings reflected the Temple rites and ritual practices. One example is the ruling introduced by Raban Yochanan ben Zakai (died $90 \mathrm{CE}$ ), an important leader during the Great Revolt and the destruction of the Second Temple, whereby the branch of a palm tree should be taken on all 7 days of Succoth, as customary in the Temple (Sukkah 83:12). Other customs included utilising elements taken from the Temple in the synagogue design, for example, placing the entrance to the synagogue in the east and having it resemble the door of the Temple and the Gate of Nicanor, designing the ark in a form reminiscent of the Temple facade, and so on (Grossberg 1994; 1998).

Incense was chosen as a symbol commemorating the Temple because of its role as a conspicuous and central ritual component of the Temple proceedings. The incense offering was regularly burned in the Tabernacle and in the Temple twice daily, in the morning and at twilight, and for this reason it was called ketoret hatamid [meaning, regularly burning incense]) (Ex 30:7-8). The afternoon hour at which the incense was burned in the Temple was considered a time of good will (Jerusalem Talmud, Berachot 4:1, 7b; Grintz 1986:139-140). According to a tradition mentioned in the Bavli (Yoma 44a), incense atones for sins, which is why the High Priest would burn it on the Day of Atonement on behalf of the entire Israelite congregation. As a result of all these factors, the burning of incense, and in time the reciting of pitum haketoret [i.e. the 'incense offering' recitation, see below], were perceived as a natural component of synagogue liturgy.

As noted by Aharon Oppenheimer (2007:189), as a rule there is no halakhic prohibition against burning incense in the absence of the Temple. However, Raban Yochanan ben Zakai, who instituted various rulings in commemoration of the Temple, chose not to include incense in the synagogue rituals. Nonetheless, there are written sources and archaeological testimonies from the fourth century on that indicate the use of elements related to incense in the art, prayer arrangements and practices of synagogues.

Incense braziers are among the material find (decorations, reliefs and mosaics) from ancient synagogues in the Land of Israel. One example was found in the mosaics of the Beit Alfa synagogue, from the Byzantine period, produced between 518 and 527 during the rule of Justin I. Rachel Elior (2004) writes about the practice of using Temple symbols in synagogue art in the period after the destruction of the Second Temple:

Distinct Temple symbols related to the sacrificial rites and to the Jewish holidays, such as the incense brazier, the ram's horn, and the date palm branch, previously associated with the Temple, were copied from the Temple to the visual dimension of the synagogue. Fertility symbols associated with the Temple, such as pomegranates, the first fruit, and the seven species, also underwent an artistic transformation and a liturgical transformation from their priestly Temple-related origins to the liturgical ritual context of the synagogue. (p. 116)

\section{Burning incense in ancient Samaritan and Rabbinic synagogues}

Israeli archaeologist, Nehemia zuri (1967:149-167), noted the burning of incense at the Jewish synagogue in Beit Shean, 
which was established in the late fourth or early fifth century and remained erect until at least 624. One of the finds uncovered at the synagogue was a bronze incense burner similar to examples found in Latakia, Syria (Ross 1965:42-45). This incense burner is constructed of two pieces. The bottom piece is a type of perforated box with four intricate legs, while the upper piece is a cone-shaped cover. Finding the incense burner in a synagogue in the Land of Israel appears to indicate that here, specifically, attempts had been made to preserve parts of the demolished Temple, which had served in practice as the spiritual centre of all the diasporas, in people's consciousness and memory. The material find indeed points to the utilisation of incense in synagogues, but it does not give any indication of when the incense was burned or at what period it became integrated in ancient Jewish liturgy.

We also have evidence of the burning of incense in an ancient Samaritan synagogue. An incense holder made of copper was found at the Samaritan site in Qedumim (1650/1793), which was inhabited intermittently during the Roman and Byzantine periods. Israeli archaeologist, Yitzhak Magen (2002a:253-257; 2002b:432), posits that the vessel probably belonged to the local synagogue, indicating that the Samaritans had burned incense in the synagogue. In the Samaritan version of the Torah (Tal \& Florentin 2010:289), similar to the Masoretic version, burning incense was associated with the Temple and not with the synagogue (Ex 30:33-38; Tal \& Florentin 2010:287). ${ }^{2}$ In any case, this practice found its way into the Samaritan place of prayer, apparently after the destruction of the Samaritan temple on Mount Gerizim (see below). This temple was built by Sanballat II in the fourth century BCE and was destroyed in 112 or 111 BCE by John Hyrcanus (approximately 164-104 BCE). Established knowledge of Samaritan synagogues exists only from around the mid-4th century (Safrai 1977:90). Hence, it is hard to know when exactly Samaritan synagogues first originated and when incense was first used in them as part of the rituals mentioned in the Torah (Pentateuch).

Burning incense remains a current practice in Samaritan synagogues. The Samaritans burn incense in the synagogue every Sabbath Eve before the Sabbath, as it is forbidden to light a fire on the Sabbath (Ha-Cohen 2017). Incense is also burned on festivals (Figures 1 and 2). According to Menashe Zedaka (2009), during the morning prayers on the Days of Forgiveness (selichot) between the Festival of the Seventh Month (the equivalent of the Jewish New Year) and the Day of Atonement, the priest who leads the prayers burns incense in a unique vessel called a Mabkhara (from Arabic: مبخرة). He passes among the congregants and atones for them, as it is written: 'And the priest shall make atonement for the whose Israelite community, and they will be forgiven' (Num 15:25; Tal \& Florentin 2010:453).

Samaritan priest, Yefet Ben Asher, contends that burning incense in Samaritan synagogues takes the place of the incense

2.Interestingly, the Masoretic verses in Exodus 30:1-10 that deal with the Golden Altar used for incense in the Tabernacle do not appear in the Samaritan version.

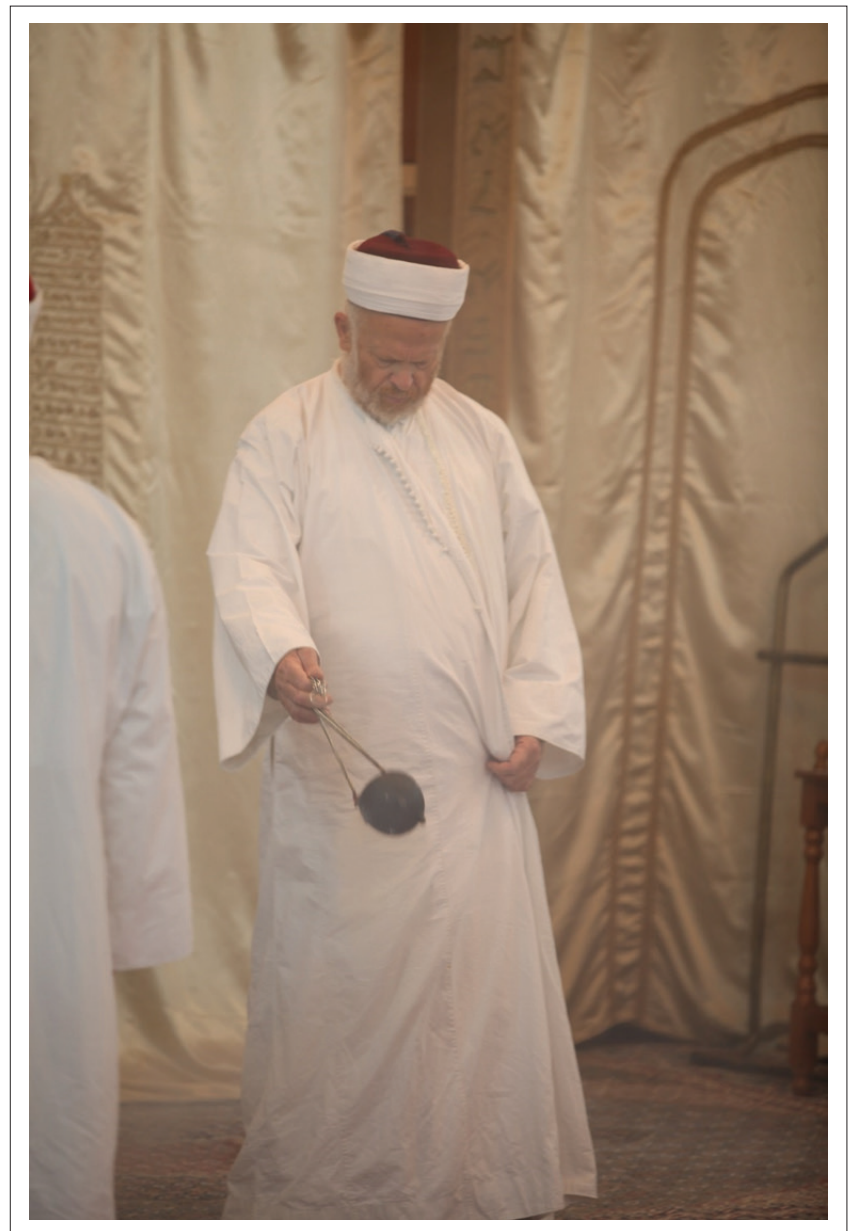

Source: Photo taken by Dr. Ori Orhof

FIGURE 1: The Samaritan priest-cantor Assaf ben Tavia hold the Mabkhara, a vessel that contains hot coals for burning the aromatic materials.

burned in the demolished Samaritan temple on Mount Gerizim, as the synagogue is a type of temple (Ha-Cohen 2017). Hence, both the Jewish and Samaritan faith had a similar process of burning incense 'in commemoration of the temple'.

\section{Burning incense in synagogues in light of the medieval Rabbinic- Karaite debate}

Burning incense in synagogues is an issue attested to in medieval Karaite anti-Rabbinic polemic. In 1922 Jacob Mann, a prominent researcher of the Cairo Genizah, published a Karaite Genizah fragment mentioning that Rabbinic Jews burn incense and light candles in the synagogue. The author of this fragment came out strongly against this custom, which he perceived as an abomination, and he writes:

And it is forbidden in current times to burn incense and to light candles [ $=$ in the synagogue $[\ldots]$ as done by the Rabbis, as it says 'It is an abomination to me' [based on Isaiah 1:13]. (Mann 1922:277-278 $)^{3}$

In his book Texts and Studies in Jewish History and Literature, Jacob Mann (1935:II, 5) ascribed this statement 3.The English translation of the biblical verses is according the Revised Standard Version (RSV). 


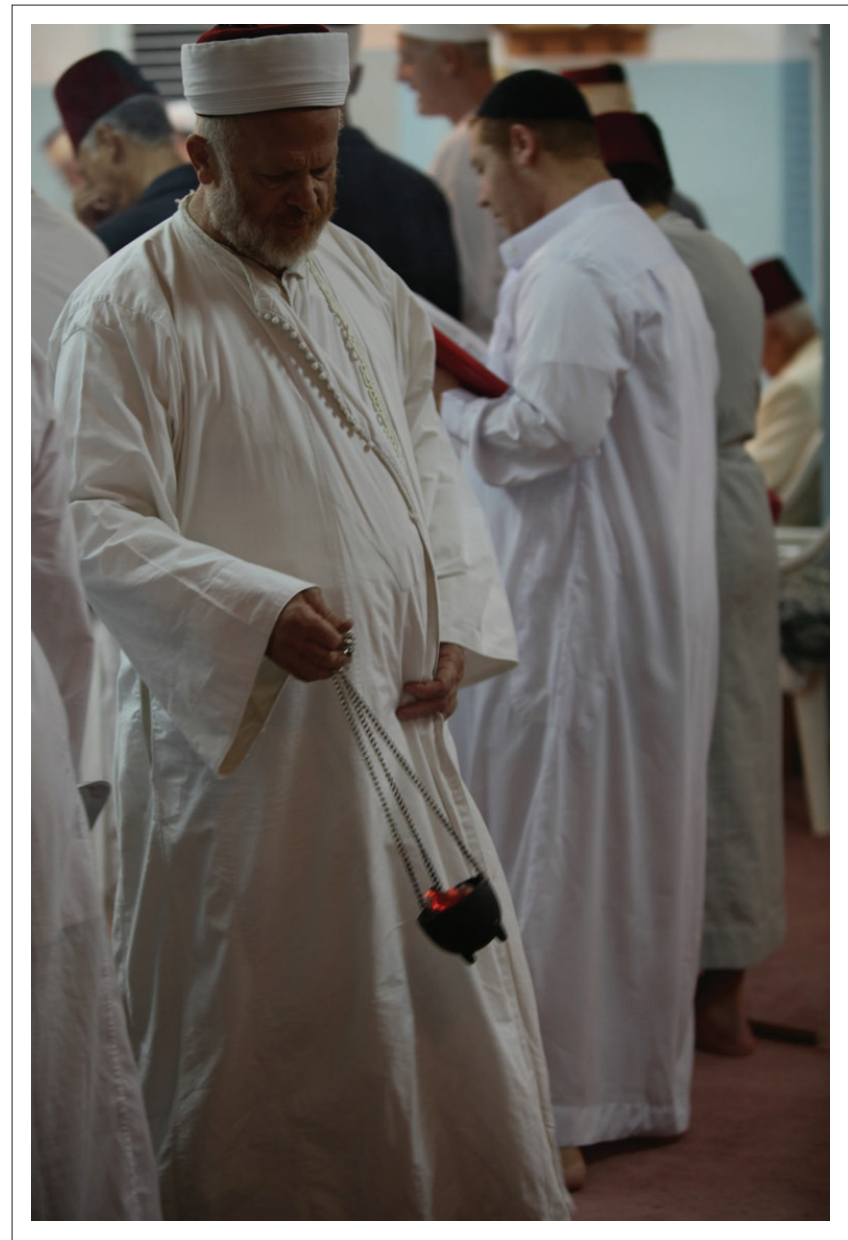

Source: Photo taken by Dr Ori Orhof

FIGURE 2: Assaf ben Tavia passes among the congregants and atones for them by waving the incense vessel.

to Daniel Alqumsi, a tenth century Karaite, based on the discovery of fragments with similar contents attributed to him. Mann brings in his book part of Alqumsi's exegesis on 'The Twelve' ('Pitron [= interpretation] to the Twelve'), in which he reports that on the tenth of Tevet and on other days Rabbinic Jews apply blood to the synagogue doors and burn incense:

And they [= the Rabbis] also sacrifice and call it offering on the tenth of Tevet and on other dates, as well as applying blood to the doors [It seems the doors of their houses. Compare: Exodus 12:7] and burning incense in all synagogues. (Mann 1935:II, 76. See also Alqumsi 1958:7)

Alqumsi's main contention is that operations and rituals carried out at the Temple should not be performed in the synagogue. Burning incense or lighting candles, as lit in the Tabernacle and in the Temple and in the Golden Menorah (Ex 30:8), are acts befitting the Temple exclusively and the synagogue should not be perceived as a replacement (Ta-Shma 2003:205). ${ }^{4}$ When these acts are performed in the synagogue they should be considered an abomination, and therefore the custom is a mark of disrespect towards the synagogue.

4.A Karaite Genizah fragment brought by Ta Shma claims that candles should not be lit in the synagogue as it should not be perceived as sacred, a claim indicating the overall refusal of the Karaites to accept the destruction of the Temple.
A similar claim appears in other Karaitic sources as well. Judah Hadassi, a Karaite theologian and biblical scholar who lived and operated in twelfth century Constantinople, objects to this practice even more strongly. Hadassi called himself 'ha-Abel' (the Mourner) because of his profound grief over Israel's exile and the destruction of the Temple, to which he often gives expression in 'Eshkol ha-Kofer'. In this book, he writes about the abominable customs of the rabbis:

And it is right to elaborate and embellish them [= the synagogues] in sanctity and purity and to honor them: but it is not right nor worthy of God to burn incense there or to light candles and oil lamps and torches at present and to say these are for God [...] as all these and similar acts were appropriate for the Temple of God but not in our times [...] because the place is not sacred, and the rites are not sacred, and the person making the sacrifice is foreign and not sacred, and the oil is impure and unholy [...] all of this is not desirable to God today, similar to all things holy: incense and candles and oil lamps and torches and offerings and sacrifices and all burning of incense. (Hadassi 1876:51d)

In other words, acts involving burning incense and lighting candles are only appropriate for the Temple and their status is like that of all other things sacred (sacrifices, offerings) that are limited to that complex. Utilising them in a synagogue is considered idolatry and anyone doing so is a sinner, as these acts must be undertaken only by priests and not by a foreign person who is not sacred and has no part in conducting the rituals (compare Num 3:10: 'If any one else comes near, he shall be put to death').

Up to this point, we have presented the Karaite words of reproach without portraying the rabbinic explanations for burning incense. A Karaitic source published by Zuker (1959) offers this explanation:

But those who require the lighting of candles and the burning of incense in synagogues are the Rabbinic Jews and they cite the verse 'And I shall be a diminished temple unto them' as support for the sanctity of synagogues. (pp. 170-171)

Rabbinic Jews claimed that the synagogue is considered a diminished Temple (based on Ezk 11:16) and a type of replacement for the Jerusalem Temple, and for this reason signs and customs utilised in the destroyed Temple may be used in the synagogue. The Karaites, however, did not accept this and claimed that the synagogue had been granted unwarranted tokens of sanctity.

As stated above, in the 'Interpretation to the Twelve' Alqumsi says that the ritual activity of Rabbinic Jews, which included burning incense in the synagogue, was implemented on 'the tenth of Tevet and other dates'. Jacob Mann claimed that incense was burned on Simchat Torah, but he brought no supporting evidence (Mann 1935:II, 76). It may be assumed that this suggestion originated from the Jewish medieval custom of burning incense (mugmar) in honour of the Torah scrolls on Simchat Torah, but this has no basis in Alqumsi's words (Ibn Giat 1861:1, 117; Sperber 1991:I, 128-131). 
Saul Lieberman (1939:9-10) also refuted Mann's contention and suggested that the tenth of Tevet has another meaning beyond that related in the Scriptures. He shows that according to some sources Jesus was born on the ninth of Tevet; thus, the Jews burned incense and offered sacrifices the next day. Lieberman himself, however, admits that he has no explanation for the nature and meaning of this 'joyful event' and how this date was connected to sacrificial acts. In my opinion, a completely different approach is in order, and the custom of burning incense should not be linked to Christmas. It makes more sense to say that burning incense on the tenth of Tevet was a symbolic custom aimed at denoting the first day of the siege on Jerusalem, which ultimately led to the destruction of the Temple and termination of the incense and sacrifice rituals (II Kings 25:1; Jr 52:4).

In fact, the sources that refer to burning incense in a synagogue are external (Karaite and not Rabbinic) and relatively few, such that it is hard to know for sure how common this practice was in Rabbinic synagogues. Moreover, the sources documenting it include no information on the perfumes used nor details of the ceremony.

At present, we have no historical sources later than the 12th century that document actual burning of spices in the synagogue. Beginning from the period of the Geonim, however, incense was included in the synagogue as part of the liturgy, and the 'incense offering', a baraita describing the preparation of the incense, its ingredients, and how it was offered up in the Temple, began to be recited (Elior 2004:117). Rav Amram Gaon, who headed the Sura Yeshiva from 853 to 871 , writes that the 'incense offering' is recited in the morning and evening prayers in commemoration of the Temple incense that had previously been offered at these times of the day (Amram Gaon 1971:40). It is not unfeasible that reciting this formula replaced the custom of burning incense in the synagogue, maybe even as a result of the Karaite criticism, however, we have no Rabbinic source that supports this.

Ta-Shma (2001:59-60) and Wieder (1998:I, 209) discussed how reciting the 'incense offering' evolved within the adjudication traditions of Jewish law and custom in medieval Ashkenaz, France and Spain, and there is no need to dwell any further on the matter. I shall only state that the 'incense offering' is at present recited as part of the Shacharit and Mincha liturgy, but not in the evening prayer of Ma'ariv.

\section{Conclusion}

Burning incense in the synagogue in commemoration of the Temple might have been inspired by the story in Jeremiah 41:5 that mentions burning frankincense in the Temple Mount complex in Jerusalem after the destruction of the First Temple. Then again, it may be a custom formed independently, with the aim of continuing and preserving the mystical, essential and beneficial force of the Temple incense.
As far as we know, burning incense in Rabbinic synagogues in commemoration of the destruction was only practiced within the Land of Israel. We hear about the implementation of this custom in Samaritan and Rabbinic synagogues only several centuries after the destruction of the Samaritan and Jewish Temples. The Samaritans still burn incense in their synagogues at certain times, but among Rabbinic Jews the custom came to an end, probably in the Middle Ages (The latte testimony is from the 12th century).

Burning incense in the synagogue in commemoration of the Temple was a point of controversy between the Karaites and the Rabbinic Jews, and it may have been discontinued as a result of the strict Karaite objections to this custom for concern of idolatry. Burning incense in commemoration of the Temple indeed ceased, but this practice remained in evidence until the 19th century for purposes of conveying respect or on festive occasions.

\section{Acknowledgements Competing interests}

The author declares that he has no financial or personal relationships which may have inappropriately influenced him in writing this article.

\section{References}

Alqumsi, D., 1958, Pitron [=Interpretation] of the twelfth: Commentary on the twelfth, I.D. Merkon edn., Mekize Nirdamim, Jerusalem.

Amar, Z., 2002, The book of incense, Eretz, Tel Aviv.

Amram Gaon, S., 1971, Seder rav Amram Gaon, D.S. Goldschmidt edn., Mossad haRav Kook, Jerusalem.

Artom, A.S. \& Cassuto, M.D., 1976, Bible: Commentaries, pictures and maps, Yavneh Press, Tel Aviv.

Bula, M., 1984, Jeremiah book, Mossad ha-Rav Kook, Jerusalem.

Elior, R., 2004, 'Hekhalot and merkavah literature: Its relation to the temple, the heavenly temple and the "Diminished Temple"', in L.I. Levine (ed.), Continuity and renewal - Jews and Judaism in Byzantine-Christian Palestine, pp. 107-142, Yad renewal - Jews and Judaism in Byzantine-Christian Palestine, pp. 107-142, Yad
Yitzhak ben Zvi, Dinur Center for Research in Jewish History \& The Jewish Theological Seminary, Jerusalem.

Felix, Y., 1976, The World of the Biblical plants, Massada, Ramat Gan.

Felix, Y., 1997, Trees: Aromatic, ornamental and of the forest, in the Bible and rabbinic literature, Rubin Mass, Jerusalem.

Grintz, Y.M., 1986, The Book of Judith: A reconstruction of the original Hebrew text with introduction, commentary, appendices and indices, The Bialik Institute, Jerusalem.

Grossberg, A., 1994, 'Ancient synagogues and the temple', in H. Branover \& I. Coven Attia (eds.), Science in the light of Torah: B'Or Ha'Torah Reader, pp. 237-254, Jason Aronson, Northvale, NJ.

Grossberg, A., 1998, 'A temple in the synagogue', Erez 61, 35-39.

Ha-Cohen, Y., 2017, The Samaritan museum manager, Beracha, Grizim Mountain, Samaria, 44835, viewed 18 June 2017, from http://www.samaritans-museum. $\mathrm{com} / \mathrm{h} / \# ! /$ portfolion.htm

Hadadi, A.H., 1865, Responsa va-Yikrah Abraham, Eliyau ben Amozed Press, Livorno.

Hadassi, J., 1876, Eshkol ha-Kofer, Mordechai Tirishken Press, Gozlo.

Ibn Giat, R.Y.J., 1861, Sha'are Simhah, Zommer Press, Fürth.

Ibn Zimra, R.D., 1882, Responsa Radbaz, Zetzer and Shriptgisser, Warsaw.

Lieberman, S., 1939, Sheki'in. On Jewish legends, customs, and literary sources found in Karaite and Christian polemical writings, Bamberger \& Voormann, Jerusalem.

Lifshitz, O., 1998, 'Jerusalem and the temple between the destruction of the first temple and the days of the return to Zion', in E. Baruch (ed.), New studies on Jerusalem, Proceedings of the Fourth Conference, pp. 27-39, Bar Ilan University, Ramat Gan.

Magen, Y., 2002a, 'The areas of Samaritan settlement in the Roman-Byzantine Period', in E. Stern \& H. Eshel (eds.), The Samaritans, pp. 245-271, Yad Yitzhak ben Zvi, Jerusalem. 
Magen, Y., 2002b, 'Samaritan synagogues', in E. Stern \& H. Eshel (eds.), The Samaritans, pp. 382-443, Yad Yitzhak ben Zvi, Jerusalem.

Mann, J., 1922, 'A Tract by an Early Karaite Settler in Jerusalem', JQR 12(3), 257-298. https://doi.org/10.2307/1451455

Mann, J., 1935, Texts and studies in Jewish history and literature, vol. 2, Hebrew Press of the Jewish Publication Society of America, Philadelphia, PA.

McKane, W., 1996, International critical commentary on the Holy Scriptures of the Old and New Testaments, a critical and exegetical commentary on Jeremiah, vol. 2: Commentary on Jeremiah, vol. Xxvi-Lii, Bloomsbury T\&T Clark, Edinburgh, pp. 26-52.

Nordlingen, Y.Y.H., 1965, Yosef Ometz, Frankfurt am Main 1928, reprint, Hermon Press, Jerusalem.

Oppenheimer, A., 2007, Rabbi Judah ha-Nasi, Zalman Shazar, Jerusalem.

Ross, M.C., 1965, Catalogue of the Byzantine and Early Mediaeval Antiquities in the Dumbarton Oaks Collection: Jewelry, enamels and art of the migration perion, Dumbarton Oaks, Washington, DC.

Safrai, Z., 1977, 'Samaritan synagogues in the Romano-Byzantine period', Cathedra 4 84-112.
Sperber, D., 1990, The customs of Israel, vol. 1, Mossad ha-Rav Kook, Jerusalem.

Tal, A. \& Florentin, M., 2010, The Pentateuch: The Samaritan version and the masoretic version, Tel-Aviv University Press, Tel-Aviv.

Ta-Shma, I.M., 2001, The Revealed in the Hidden: The Halakhic Residue in the Zohar, ha-kibbutz ha-meuchad, Tel Aviv.

Ta-Shma, I.M., 2003, The Early Ashkenazic prayer: Literary and historical aspects, Magnes, Hebrew University, Jerusalem.

Wieder, N., 1998, The Formation of Jewish Liturgy in the East and the West: A Collection of Essays, vol. II, Yad Yitzhak ben Zvi, Mechon ben Zvi for the Research of Israel Communities \& Hebrew University Hebrew University, Jerusalem.

Zedaka, M., 2009, 'The custom of The Tenth Days of the Selichot (Forgiveness)', Samaritan Community Website, viewed 16 October 2009, from http://www. tapuz.co.il/blogs/viewEntry/1567474

Zuker, M., 1959, On the Translation of Rabbi Sadiyah Gaon on the Torah, Feldheim, New York.

Zuri, N., 1967, 'The ancient synagogue in Beit She'an', Eretz Israel 8 [Sukenik Book], 149-167. 